\title{
Meer voor minder
}

Citation for published version (APA):

von Meyenfeldt, M. F. (1994). Meer voor minder: op zoek naar nieuwe balansen. Maastricht University. https://doi.org/10.26481/spe.19941014mm

\section{Document status and date:}

Published: 14/10/1994

DOI:

10.26481/spe. $19941014 \mathrm{~mm}$

Document Version:

Publisher's PDF, also known as Version of record

\section{Please check the document version of this publication:}

- A submitted manuscript is the version of the article upon submission and before peer-review. There can be important differences between the submitted version and the official published version of record.

People interested in the research are advised to contact the author for the final version of the publication, or visit the DOI to the publisher's website.

- The final author version and the galley proof are versions of the publication after peer review.

- The final published version features the final layout of the paper including the volume, issue and page numbers.

Link to publication

\footnotetext{
General rights rights.

- You may freely distribute the URL identifying the publication in the public portal. please follow below link for the End User Agreement:

www.umlib.nl/taverne-license

Take down policy

If you believe that this document breaches copyright please contact us at:

repository@maastrichtuniversity.nl

providing details and we will investigate your claim.
}

Copyright and moral rights for the publications made accessible in the public portal are retained by the authors and/or other copyright owners and it is a condition of accessing publications that users recognise and abide by the legal requirements associated with these

- Users may download and print one copy of any publication from the public portal for the purpose of private study or research.

- You may not further distribute the material or use it for any profit-making activity or commercial gain

If the publication is distributed under the terms of Article $25 \mathrm{fa}$ of the Dutch Copyright Act, indicated by the "Taverne" license above, 


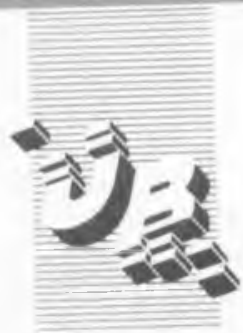

De uitieentermijn verstrijkt op

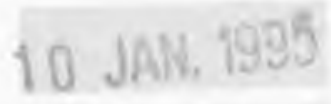

\section{OKT. 1995}

Rıjksuniversileit Limburg

Posibus 616

6200 MD Maastrich

Gelieve deze publicatıe tijdig te relourneren of (telefonisch) verlenging van de uileentermın aan te vragen

UNIVERSITEITSBIBLIOTHEEK RU LIMBURG 


\title{
MEER VOOR MINDER \\ OP ZOEK NAAR NIEUWE BALANSEN
}

\author{
REDE \\ in verkorte vorm uitgesproken bij de aanvaarding van het \\ ambt van hoogleraar in de Algemene Heelkunde \\ in het bijzonder de Chirurgische Oncologie \\ aan de Rijksuniversiteit Limburg \\ op vrijdag 14 oktober 1994 \\ door \\ DR. M.F. VON MEYENFELDT
}




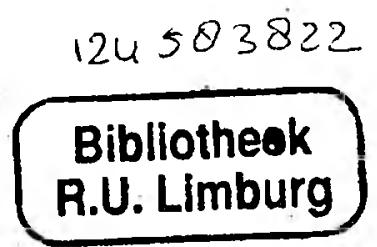

"When the going gets tough, the tough get going" Randy Newman 
Mijnheer de Rector,

zeer geachte toehoorders.

In één van de vele fraaie straten van Maastricht woont een mevrouw die in het afgelopen weekend een knobbeltje in haar linker borst heeft ontdekt. Maandag was zij bij haar huisdokter en die bevestigde haar eigen bevinding. Hij zond haar door voor een foto, een mammografie, en vroeg de radiodiagnost, zoals eigenlijk altijd, of hij de patiënt wilde doorsturen, indien hij afwijkingen zou zien. En inderdaad, de radiodiagnost zei dat hij iets op de foto had gezien en dat een bezoek aan de chirurg gewenst was: hij had al gebeld en ze kon direct terecht. Die chirurg had haar, nadat ze enige tijd had moeten wachten, vriendelijk maar toch gehaast ontvangen: hij had haar vlug onderzocht, nog snel een blik op de foto's geworpen' en toen gezegd dat er nog meer onderzoek gedaan moest worden: een prik in de knobbel die ze had gevoeld, er zou wat bloed worden afgenomen en er zou nog een röntgenfoto van de longen gemaakt moeten worden. En tenslotte had hij ook nog gezegd, dat de knobbel verwijderd moest worden en dat hij haar daarom ook maar direct naar de opname zou sturen. In het ziekenhuis, bij die opname, zou hij haar dan weer zien en dan zouden zij wel verder praten.

Dit had ze allemaal onthouden, maar wat betekende dat? Waarom die prik in de borst; waarom bloed geprikt, waarom die longfoto? Wat was de chirurg van plan in het ziekenhuis? Ze had wel eens wat gelezen over borstkanker, maar had ze dat nou of niet? En als ze borstkanker had, hoe kwam zij er dan aan? Haar man was niet met haar mee geweest en kon haar nu dus ook niet verder helpen. Het is nu vrijdag, mevrouw heeft van het ziekenhuis gehoord dat ze maandag moet komen voor opname. 
MEER VOOR MINDER

Was deze mevrouw patiënte geweest in het oude China in \pm de 7 e eeuw voor Christus dan zouden de antwoorden op deze vragen (aanzienlijk) simpeler geweest zijn. In het oudste geneeskundig handboek uit China, de Huang Di Neiching, dat uit die tijd stamt, is te lezen dat gezondheid werd gezien als resultaat van het samenspel van wezenlijke krachten in de natuur: het actieve, lichte, droge, warme, positieve, mannelijke Yang, en het passieve, donkere, koude, vochtige, negatieve Yin. Alles, concrete materie of belevingen, maar ook de onbewuste materie, was een combinatie van deze beide fundamenten. Het hoogste principe in het universum was de Tao, de weg, het rechte pad, in overdrachtelijke zin, die de juiste verhouding tussen Yin en Yang bepaalde. Alles wat de natuurlijke relatie tussen Yin en Yang verstoorde was slecht. Het hoogste goed in het leven was het volgen van de Tao. Volgens de oude Chinese fysiologen (!) en ook nog in het hedendaagse China geloofd, bestaan er in de mens 3 stromingen: het Jing, het odem Qi, en de genius Shen. Deze 3 begrippen moeten los gezien worden hun lichamelijke equivalenten. Leven zonder Jing, Qi of Shen is niet mogelijk. Wordt één van de drie in hun samenwerking gehinderd, dan sterven de andere twee en eindigt het leven. Jing is het uiterlijk potentieel van de uiterlijke vorm der veranderingen, bijvoorbeeld de aanmaak en afbraak van eiwitten. Shen is een hogere vorm van energie, de "ziel" die het Jing in staat stelt zijn taken te verrichten. Qi is de oerkracht, de levenskunst, Qi is overal aanwezig en werkt ook als een energie drager. Qi gaat voortdurend verloren, omdat het de energie levert voor de afvoer van de verbruikte lichaamssappen. Aanvulling geschiedt vanuit de lucht en uit het voedsel. Het daaruit voortkomende "zuivere", nieuwe Qi circuleert via energie lijnen (niet te verwarren met bloedvaten) via "meridianen" naar de verschillende organen. Bij ziekte is er een zwakke plek in de meridiaan, hoopt afgewerkte stoffen dragend Qi zich op, kan dan uitstralen naar de omgeving en maakt zo het betreffende orgaan ziek.

De chirurg die onze patiënte onderzocht, had het resultaat van de nega- 
tieve overheersing van het Yin gezien, maar had verzuimd te zien, dat hij poliklinisch al had moeten beginnen met het versterken van de positieve invloed van het Yang. In het oude, maar ook in het hedendaagse China werd dat bereikt door patiënte d.m.v. concentratie en bepaalde lichaamsoefeningen in staat te stellen de Qi, de lichaamskracht naar de zieke plaats te dirigeren zodat de balans tussen Yin en Yang hersteld kon worden. Zou de chinurg belangstelling voor de oncologie gehad hebben, dan zou hij wel oog gehad hebben voor het herstel van de balans tussen Yin en Yang bij onze patiënte; hij zou oog gehad hebben voor de ontreddering en gepoogd hebben die door voorlichting voor patiënte te structureren; hij zou oog gehad hebben voor de balancering van de verschillende therapie opties, afhankelijk van de leeftijd en de stagering van de ziekte èn hij zou oog gehad hebben voor de inbreng van patiënte in het maken van de therapie keuze.

\section{Chirurgische oncologie: de Tao}

Net als de tao-istische kijk op gezondheid en het behoud ervan zich verder ontwikkelde door invloeden van buitenaf en kruiden en medicamenten uit Mesopotamië, Syrië en Egypte hun intrede deden, zo heeft ook de behandeling van tumoren, waarin chirurgie vanouds de belangrijkste behandeling vormde, zich verder ontwikkeld. Met name in de afgelopen decennia zijn er effectieve niet-chirurgische behandelingsmogelijkheden ontwikkeld waarmee de moderne chirurg rekening dient te houden. Vele van die nieuwe ontwikkelingen worden niet door de chirurg zelf uitgevoerd, maar door andere in het oncologisch veld werkzame specialisten.

Chirurgie heeft een rol in de preventie van kanker, door die organen die een voorstadium van kanker vertonen, te verwijderen. Daamaast bestaat een door de voortgaande ontwikkeling van nieuwe technieken steeds kleiner wordende rol in de diagnostiek van kanker. Verreweg de belang- 
rijkste rol is de behandeling van kanker: de resectie, met de bedoeling patiënt te genezen, of de operatie die bedoeld is om de symptomen, de last van de ziekte, te verminderen. Ten derde de resectie van een gedeelte van de tumor met de bedoeling door andere, effectieve therapiemaatregelen een verdere tumorreductie te verkrijgen. Ten vierde de resectie van uitzaaiingen, waarmee in een weliswaar klein, maar toch belangrijk deel van de patiënten alsnog genezing kan optreden en ten vijfde de chirurgie ten behoeve van functie-herstel en reconstructie, vaak in samenwerking met de plastisch en reconstructief chirurg uitgevoerd.

Daarmee blijft de chirurg, ook nu nog, een spin in het web van de kankerbehandeling, met vele draden naar oncologische zusterdisciplines. De chirurg moet op de hoogte zijn van de mogelijkheden en beperkingen van de niet chirurgische behandeltechnieken. Als hij daarbij in gebreke blijft, verliest hij zijn geloofwaardigheid als gelijkwaardig gesprekspartner in de ogen van zijn collega-oncologen en dreigt het reële gevaar, dat de bijdrage van de chirurg in het totale behandelingsconcept van een patiënt met een solide tumor besloten ligt tussen de bordjes "IN" en. "UIT" van het operatiekamer complex. Om die geloofwaardigheid te behouden en soms zelfs terug te winnen, is versmalling en verdieping van de aandacht van de chirurg in het gehele gebied van de kanker-behandeling en daarmee ook in de bijdrage van de chirurgie daarin, noodzakelijk. Per chirurgische groep zal derhalve één chirurg zich moeten toeleggen op de behandeling van oncologische of potentieel oncologische pathologie. Afhankelijk van de grootte van de groep en de hoeveelheid oncologische pathologie, die wordt aangeboden kan het soms zelfs noodzakelijk zijn meerdere oncologisch-chirurgen in een groep te hebben. Hij blijft een vertegenwoordiger van één van de moederspecialismen, waartoe clinici behoren die overzicht behouden hebben over het geheel van het menselijk ziek zijn en die geleerd hebben de juiste prioriteit te geven aan de verschillende problemen die de ouder 
wordende bevolking presenteert.

Chirurgische oncologie: het Yin

Tot zover lijkt het verhaal logisch; de werkelijkheid is echter anders. Lawrence beschreef in 1986 in een onderzoek bij 124 universitaire chirurgische afdelingen in de V.S., dat slechts $38 \%$ een divisie chirurgische oncologie bezat in vergelijking tot aanwezigheid van een divisie medische oncologie in $95 \%$ van de gevallen. Formele afdelingen bestralingsoncologie waren aanwezig in $94 \%$ van de klinieken, kinderoncologie in $76 \%$ en gynaecologische oncologie in $79 \%$ van deze instituten. Van de 47 afdelingen chirurgische oncologie bezaten slechts 13, dat is ongeveer een kwart, een formele opleiding chirurgische oncologie. De situatie in Nederland is niet heel anders. Na Leiden is in Maastricht als tweede - en binnenkort zal de Vrije Universiteit als derde faculteit geneeskunde volgen - een structureel ordinariaat chirurgische oncologie ingesteld. In vrijwel alle universiteiten bestaan daarentegen structurele leerstoelen medische oncologie. Voortgezette opleidingen in de chirurgische oncologie bestaan in Groningen, aan het VU ziekenhuis en in Leiden, terwijl - en mijn mede inaugurator wees er al op - in de meeste universitaire klinieken een voortgezette opleiding medische oncologie bestaat. Naast dęze beperkte opleidingscapaciteit is ook de belangstelling voor deze voortgezette opleiding beperkt. Dit alles heeft er o.a. toe geleid dat er een tekort aan chirurgisch oncólogen in Nederland bestaat, als dat gemeten wordt aan de hand van beschikbaar zijn van chirurgisch oncologen voor de multidisciplinaire consulententeams, die opereren in het werkgebied van elk van de 9 integrale kankercentra; slechts 52 van de 118 consulententeams zijn volledig. De ontbrekende discipline is vrijwel steeds de chirurgische oncologie. Bovendien geven met name de grotere chirurgische maatschappen aan, geen behoefte te hebben aan een chirurgisch oncologisch consulent.

De reden van de geschetste discrepantie, de te grote invloed van het 
negatieve Yin, is niet duidelijk. Aan de ene kant de erkenning dat er een speciale rol is weggelegd voor de chirurg die zich bezig houdt met kankerbehandeling. Aan de andere kant een geringe belangstelling en, zo lijkt het, een geringe behoefte.

Een belangrijke reden zou kunnen zijn, dat de chirurgische behandeling van tumoren gebaseerd is op veelal klassiek te noemen technieken en dat er, zeker in vergelijking tot wat er in andere vakgebieden op dit terrein gedaan is, zeer weinig prospectief vergelijkend onderzoek werd uitgevoerd naar de effectiviteit van verschillende chirurgische technieken. Daarmee is ook weinig cijfermateriaal beschikbaar, waaraan de uitkomst van een chirurgische behandeling van een maligniteit kan worden getoetst. Niettemin worden frequent betere resultaten geclaimd van meer uitgebreide chirurgische resecties of speciale operatietechnieken. Eén van die claims geldt de no-touch isolation technique, waarin bij de resectie van coloncarcinomen eerst de vaatsteel wordt onderbonden, vervolgens het colonlumen ter weerszijde van de tumor wordt onderbonden, alvorens tot resectie van het betrokken colonsegment over te gaan. Deze claim was afkomstig van ongecontroleerd onderzoek en vormde voor de Maastrichtse universiteitskliniek in de jaren zeventig aanleiding een prospectief gecontroleerd onderzoek op te zetten. De resultaten daarvan werden door Wiggers bewerkt in een proefschrift en door ons recent opnieuw geëvalueerd na een follow-up van minimaal 10 jaar. De resultaten toonden en tonen opnieuw een heldere trend in de richting van een betere overleving. van de no-touch geopereerde patiënten-groep. Deze trend wordt des te duidelijker en significant in de groep patiënten waarbij de tumor angio-invasieve groei vertoonde, de groep waarbij de gevolgde operatietechniek ook in theorie de grootste winst zou moeten geven. Chirurgen hebben over het algemeen verzuimd om - zoals dat wel het geval is met vele vaak adjuvante behandeltechnieken - met de macht van het getal aan te tonen, dat de kleine verbeteringen die modificaties van behandeling - in het geval van 
chirurgie operatie techniek of operatie strategie - kunnen hebben ook werkelijk geapprecieerd worden als verbeteringen van de behandeling. Het ontbreken van goed opgezet prospectief vergelijkend onderzoek leidt daarom helaas tot de misvatting dat de gebruikte operatietechniek niet relevant is; het tegendeel wordt geillustreerd aan de hand van meerdere weliswaar retrospectieve studies, die aangeven dat de operatieve ervaring van de chirurg leidt tot een betere behandeltechniek, inclusief adequate selectie van patiënten en voorbehandelingen en vervolgens tot betere behandelingsresultaten.

\section{Chirurgische oncologie: het Yang}

Erkenning van dit gegeven - ook in de chirurgenwereld - zal het mogelijk maken dat óók chirurgen invulling geven aan het streven, neergelegd in het gezondheidsraadrapport "Kwaliteit en taakverdeling in de oncologie": :concentreren van zorg voor de kankerpatiënt binnen de maatschap bij diegene die daarvoor belangstelling heeft, en concentreren van zorg binnen de regio in een centrum, als de aantallen patiënten met een specifieke aandoening binnen die regio, of complexe en innovatieve behandelingen een dergelijke concentratie vereisen. De noodzaak tot concentratie kan zo niet alleen voortkomen uit het verrichten van een speciale behandeling. Zij kan ook het gevolg zijn van de aanwezigheid in het centrum van de voor intensieve behandeling noodzakelijke infrastructuur, waarin vele disciplines in voldoende aantal onmiddellijk beschikbaar zijn voor optimale invulling van een deel van het diagnostiek en therapie traject. Het evenwicht, de weg, de Tao, die daar het gevolg van is, moet de resultante zijn van het Yang: de masculine wens om ook zeldzame, grote tumoren te reseceren, en het negatieve Yin: de te krappe marges of het door complicaties gekenmerkte postoperatieve beloop. De chirurgische groep in Maastricht wil graag met de chirurg-oncologen in de regio nadenken over de ontwikkeling van de chirurgisch-oncologische Tao in Limburg. Wij zullen daarvoor de hulp 
MEER VOOR MINDER

inroepen van het medium dat voor dergelijke activiteiten is geschapen: het IKL.

\section{Chirurgische oncologie: de Tao}

Voor het in gang zetten van een dergelijke beweging, die moet resulteren in de Tao - het rechte pad, de leidraad - zijn een aantal randvoorwaarden nodig; deze zijn voortreffelijk verwoord in de nota Chirurgische Oncologie van de Nederlandse Vereniging voor Chirurgische Oncologie. De meest belangrijke voorwaarde is het streven te komen tot een registratie van chirurgen als chirurg-oncoloog. Hiervoor komen chirurgen in aanmerking die een erkende vervolgopleiding succesvol hebben voltooid. Goed overleg met de gastro-intestinaal chirurgen moet leiden tot werkafspraken over de behandeling van maligniteiten van de tractus digestivus: voor geen van beiden kàn gelden dat zij het primaat hebben van de behandeling van patiënten met een tractus digestivus maligniteit. In de uitwerking van die samenwerking, die per centrum kan verschillen, moet de erkenning van de aanwezige expertise leidraad zijn.

Chirurg-oncologen dienen te werken in een middels visitatie getoetste werkomgeving, waarmee zowel de groep als het instituut, perifeer zowel als centraal, bedoeld wordt. In die werkomgeving zullen samenwerkingsverbanden ontstaan, waarin perifeer en centraal werkende chirurg-oncologen evt. gezamenlijk opereren, volgens in de regio vastgestelde richtlijnen, protocols.

Het meten van uitkomst van zorg - waarbij als criteria kunnen gelden 5 jaars overleving, ziektevrije overleving, recidief percentage, morbiditeit en complicaties na behandeling, mortaliteit, functieverlies, kwaliteit van levẹn en tevredenheid van de patiënt - kan behulpzaam zijn bij het verder sturen van de organisatie van de chirurgisch-oncologische zorg in Nederland.

Tot slot zal erkenning van de grotere tijdsinvestering die nodig is in de 
behandeling van de oncologische patiënt vertaald moeten worden in waardering van die extra inspanning door de chirurg-oncoloog.

De uitwerking van deze ideeën zal op landelijk niveau de komende jaren onze - die van chirurgisch oncologisch Nederland. - aandacht hebben.

\section{Multidisciplinaire ONCOlogie: de TAO}

In Maastricht heeft het idee dat oncologische zorg alleen op niveau kan worden ingevuld, als aan het multidisciplinaire karakter daarvan ook inhoud kan worden gegeven, geleid tot vorming van een klinisch zwaartepunt oncologie. Daarin participeren alle disciplines die zich bezighouden met oncologische zorg. Onderzoek naar en erkenning van elkaars positie in relatie tot de ontwikkeling van een zwaartepunt oncologie bij zowel faculteit als ziekenhuis hebben er nu toe geleid, dat wij aan de uitbouw van een aandachtsgebied en thema oncologie kunnen beginnen. Grote prioriteit zullen wij geven aan een systeem van output-registratie in het ziekenhuis; het stroomlijnen van de algemene oncologie bespreking in die zin, dat naast de behoefte van de individuele arts een patiënt in die vergadering te bespreken, er ook een actieve selectie gemaakt wordt van patiënten wier probleem tijdens die bespreking wordt geanalyseerd. Documentatie en automatisering van de processen rondom de oncologie-besprekingen zullen worden verbeterd; de eerste aanzetten daartoe zijn al gegeven. Tot slot vereist de multidisciplinaire aanpak samenwerking in de poliklinische sfeer, meer nog dan in de klinische sfeer. Instellen van de - door mijn mede inaugurator genoemde - multidisciplinaire polikliniek oncologie zal geestelijke en materiële offers vragen van de deelnemers en van het ziekenhuis, maar bijdragen in gebalanceerde zorg. 
MEER VOOR MINDER

\section{HeT ONDERZOEK: DE TAO}

Het verlies van balans in vele fysiologische processen - dat zo vaak het kenmerk is van de aanwezigheid van kanker - is de lijn, de Tao, van het vooral metabool gekleurde heelkundig oncologisch onderzoek in Maastricht. $\mathrm{Al}$ in de dertiger jaren werd geobserveerd dat het grootste deel van de kankerpatiënten overlijdt in omstandigheden, die geillustreerd worden door verlies aan eetlust, gewichtsverlies, spierkrachtverlies en algehele lethargie. De belangstelling voor analyse van dit probleem heeft mij naar het University of Cincinnati Mediçal Center gebracht, waar ik na initiërend werk van Ruud Krause gedurende bijna 2 jaar proefdier onderzoek deed naar het ontstaan van aan kanker gerelateerde anorexie. Met een waarschijnlijk overgesimplificeerd idee dat een verstoord serotonine metabolisme in de hersenen, leidend tot een verhoogde serotonine turnover, de belangrijkste causale factor in het ontstaan van kanker-anorexie was, kwam ik uit de VS terug. Vervolgonderzoek in datzelfde University of Cincinnati Medical Center leerde dat serotonine zeer waarschijnlijk een meer beperkte rol speelt. Recent heeft de onderzoeksgroep van Rossi Fanelli in Rome echter opnieuw de aandacht gevestigd op serotonine in relatie tot het ontstaan van kanker anorexie. $\mathrm{Zij}$ onderzocht bij een groep van 24 kanker-patiënten die over verlies van eetlust klaagden, de verhouding tryptophaan over de neutrale aminozuren in het plasma. Deze ratio lijkt iets te zeggen over de beschikbaarheid van tryptophaan voor transport over de bloed-hersen barrière. Een afname van de ratio geeft een afgenomen beschikbaarheid van tryptophaan voor transport over de bloed-hersen barrière weer, leidend tot een afgenomen synthese van serotonine. Inderdaad vonden zij dat een afgenomen ratio bij deze kanker-patiënten geassocieerd was met een grotere energie-inname en als resultaat daarvan met een toename van het plasmaeiwit prealbumine.

Terug in Nederland heb ik mij gericht op onderzoek naar de verstoorde 
balans tussen voedsel-inname, energie-inname en energie-besteding bij de kankerpatiënt. Uit dat onderzoek resulteerde de waarneming dat bij maag-darmkankerpatiënten het gewichtsverlies vooral geinduceerd wordt door een afgenomen voedsel- en daarmee energie-inname; terwijl bij longkankerpatiënten de toegenomen energie-besteding - die niet anders verklaard kan worden dan uit de aanwezigheid van tumor - niet gevolgd werd door een toename van energie-inname en zo tot een negatieve energiebalans leidde. Conclusie van dit onderzoek - dat samengevat is in het proefschrift dat door Lily Fredrix werd verdedigd - was dat verschillende tumorsystemen elk op een eigen wijze verștoringen veroorzaken die leiden tot een verstoring van de energiebalans.

Herkenning van het ontstaan van ondervoeding bij de kankerpatiënt èn de erkenning dat de kankerpatiënt die tekenen van ondervoeding vertoont een grotere kans op morbiditeit van zijn behandeling heeft, een geringere respons op therapie vertoont en een korte overleving kent, leidde tot de behoefte daamaar nader onderzoek te doen. Eén van de eerste dingen die onze belangstelling had, was te trachten vast te stellen in welke mate ondervoeding bijdraagt aan de postoperatieve morbiditeit na behandeling van maag-, colon-, en rectum-carcinomen. Was het slechts een gering effect dan zou een poging om d.m.v. kunstvoeding de ondervoeding te corrigeren niet relevant zijn. Zou de bijdrage echter onafhankelijk en groter zijn dan zou dat leiden tot een goed argument om in prospectief gecontroleerd onderzoek na te gaan of het geven van kunstvoeding zou leiden tot afname van het aantal complicaties. Uit dit onderzoek - dat door Jeroen Meijerink werd geanalyseerd en beschreven in zijn proefschrift - bleek dat de aanwezigheid van ondervoeding een onafhankelijke factor was in de ontwikkeling van postoperatieve, m.n. septische complicaties na chirurgie voor maag- en colon-rectum tumoren. Het prospectief gecontroleerde voedingsinterventie-onderzoek - tot dan toe in de wereld niet in een adequate onderzoeksopzet onderzocht en hier in Maastricht als grootste single center trial uitgevoerd - 


\section{MEER VOOR MINDER}

leidde tot de conclusie dat met name bij patiënten met tekenen van emstige ondervoeding het geven van preoperatieve kunstvoeding kan leiden tot een afname van m.n. septische en infectieuze complicaties.

Noch het onderzoek dat de bijdrage van ondervoeding in het ontstaan van postoperatieve complicaties analyseerde, noch het onderzoek naar de invloed van preoperatieve voeding gaven ons zulke overtuigende antwoorden dat zij tot algemeen geaccepteerde klinische beleidsconsequenties leidden. De reden daarvan moet gezocht worden in het feit dat de beschrijving van ondervoeding zo grof en daarmee zo vaag was, dat de definiëring van de groep ondervoede patiënten die in aanmerking zou moeten komen voor voedingsinterventie onvoldoende scherp was. Hierdoor werden de gunstige effecten van kunstvoeding alleen zichtbaar in de ernstig ondervoede patiëntengroep.

NWO gunde ons een project om het fenomeen van ontwikkeling van cachexie in het proefdier en gedeeltelijk ook bij de mens nader te bestuderen. Ik wil u graag deelgenoot maken van een recent resultaat uit een stukje van dat onderzoek.

Om dat te kunnen doen moet ik u eerst laten weten wat wij onder klinische depletie verstaan. Klinische depletie beschrijft een toestand die het resultaat is van hongeren of van verhoogde energiebehoefte of van veranderde stofwisselingsprocessen, leidend tot een verlies van functie: dat kan op celniveau zijn, dat kan op weefselniveau zijn, dat kan op orgaanniveau zijn. En bij de kankerpatiënt is er - en dat meldde ik u reeds - frequent sprake van een verstoorde energiebalans. Depletie is dus bij kanker een frequent optredend probleem. Een verlies van orgaanfunctie van die organen die betrokken zijn bij de afweer van bedreigende invloeden van buitenaf kan derhalve een ernstig gevaar voor de kankerpatiënt vormen, zeker als door de therapie van kanker de functie van die orgaan-systemen nog verder wordt bedreigd. Het immuunapparaat, de huid en slijmvliezen vormen de meest belangrijke afweerorganien. De meest fragiele daarvan is waarschijnlijk de darm- 
wand waar het darmslijmvlies de barrière vormt tussen het interne milieu - waar zeer weinig micro-organismen huizen - en het "milieu extern" waar in het lumen enorme aantallen bacteriën verblijven. Het aminozuur glutamine speelt mogelijk een sleutelrol bij de instandhouding van deze voor het leven essentiële barrière-functies. Het aminozuur wordt voomamelijk in de spier gemaakt; het zou dus heel goed kunnen zijn dat in condities, die wij depletie noemen en waarbij verlies van spiermassa één van de meest in het oog springende kenmerken is, een onvoldoende hoeveelheid glutamine aanwezig is of gemaakt kan worden.

Ivo de Blaauw toonde in een tumorratmodel in ons laboratorium aan dat deze dieren geen gewichtsverlies vertonen en ook geen opvallende afname van voedselinname; ook als er sprake is van een grote tumorlast. Daarmee lijkt dit tumorratmodel heel aardig op de klinische situatie waar frequent op het eerste oog niet zo veel aan de hand is met de tumorgastheer: de kankerpatiënt. Hij toonde aan dat met toename van de tumorlast bij deze dieren een toename bestaat van eiwit turn-over, eiwit-aanmaak en eiwit-afbraak. En hij bevestigde daarmee een oude waarneming bij het kankerdragende individu. Hij toonde echter ook aan dat de glutamine-aanmaak en -afbraak toenamen met een toenemende tumorlast. Desondanks daalden de arteriële glutamine spiegels bij deze dieren progressief met een toename van de tumorlast. Ook de weefselspiegels van dit aminozuur daalden met toename van de tumorlast. Analyse van de glutamineproductie door de spier toonde aan, dat juist bij toename van de tumorlast de spier niet meer in staat blijkt in de grote behoefte van glutamine te voorzien. Wat voor consequenties deze verlaagde arteriële glutamine-spiegel en weefsel glutamine-spiegels hebben voor het functioneren van het organisme weten wij nog niet in dit tumorratmodel. De parameters die ons daarover moeten informeren zijn nog in analyse.

In een al wat langer lopend onderzoek, dat door René van der Hulst 


\section{MEER VOOR MINDER}

wordt uitgevoerd bij patiënten die aandoeningen van verschillende aard hebben - zowel maligniteiten als ontstekingsziekten van de darm - kennen we de consequenties van deze bevindingen wel. René van der Hulst toonde in een serie uiterst elegante onderzoeken bij deze patiënten aan, dat de aanwezigheid van klinische depletie geassocieerd was met significant verlaagde plasma glutamine-spiegels en daarmee ook een significante afname van de darmslijmvlies glutamine concentratie. De consequenties van deze verlaagde glutamine beschikbaarheid voor de vorm van het slijmvlies en de consequenties voor de barrière-functie van het darmslijmvlies zijn ook onderzocht. Bij deze klinisch deplete patiënten - met dus verlaagde glutamine-spiegels in plasma en darmslijmvlies bleek inderdaad een afgenomen villus-hoogte te bestaan en een afgenomen barrière-functie zoals weergegeven met een dubbel-suiker test.

Deze studieresultaten tonen aan dat het heel relevant is om te onderzoeken of de waarnemingen die we bij de kankerdragende rat deden ook bij de mens gelden. M.a.w. is er bij de mens die kanker heeft inderdaad sprake van een afgenomen produktie van glutamine, is het iets specifieks voor de kankerdragende mens of is dit iets wat past bij algemeen ziek zijn en dus ook kan voorkomen bij andere aandoeningen? Een andere heel belangrijke vraag is of de kankerpatiënt die tekenen van depletie vertoont in staat is om onder omstandigheden waarin een extra beroep gedaan wordt op afweer, voldoende eiwit af te breken en daarmee glutamine te produceren om de essentiële barrière functies die het lichaam kent in stand te houden. Naast de capaciteit om brandstoffen te mobiliseren t.b.v. essentiële lichaamsfuncties, kan ook de grootte van het trauma, dat deze noodzaak induceert, een rol spelen. We hebben daarover nu nog geen concrete aanwijzingen maar het ligt wel in onze bedoeling daar in de komende jaren een uitspraak over te doen.

Waarom vinden wij dat interessant, waarom is dat interessant?

Daarvoor wil ik u meenemen naar de resultaten van een groot nationaal onderzoek waaraan ook vanuit onze kliniek medewerking werd ver- 
leend.. Een onderzoek dat opgezet en gecoördineerd werd door collega van de Velde in Leiden en dat de effectiviteit van een heel uitgebreide in Japan gepropageerde resectie voor maagkanker wilde vergelijken met de klassieke meer beperkte Westerse operatie-procedure. Dit onderzoek is voltooid, zij het dat over de effecten op overleving nog geen uitspraak gedaan kan worden, omdat de follow-up ervoor nog te kort is. Wat wel al duidelijk is geworden, is dat de morbiditeit en mortaliteit in de patientengroep die de uitgebreide resectie onderging significant hoger is; zoveel hoger, dat een eventueel gunstig effect van de ingreep zelf op de lange-termijn-overleving ernstig versluierd kan raken. Ons onderzoek in Maastricht kan een vinger krijgen achter de veranderingen in de eiwit stofwisseling die bij de kankerpatiënt optreden en die de patiënt niet in staat stellen adequaat te reageren op het zeer grote operatietrauma dat de uitgebreide resectie inhoudt: een gebrek aan responscapaciteit die leidt tot een significante toename van morbiditeit en mortaliteit.

Het onderzoek dat ik $u$ net schetste is in de facultaire onderzoeksstructuur ondergebracht bij het instituut NUTRIM, maar past heel goed in het centrale onderzoeksthema dat alle bij de oncologie betrokken specialismen hebben gekozen, t.w. de studie naar de relatie tussen kankertherapie en de genotypische en fenotypische kenmerken van kankercellen en normale cellen. Nu er helderheid bestaat over de principiële bereidheid van faculteit en ziekenhuis onderzoek binnen dit thema in stand te houden en een groeimogelijkheid te geven, kan in de zeer nabije toekomst begonnen worden met verdere projectomschrijvingen. Dit moet tot doel hebben, dat in de toekomst het profiel van het oncologisch onderzoek in Maastricht beter herkenbaar wordt èn niet te miskennen valt in een volgend discipline-advies-geneeskunde van de KNA.W.

\section{Het ONDERWIJS: de TAO}

Het onderwijs in onze faculteit is in de pre-klinische fase gebaseerd op 
MEER VOOR MINDER

het probleem georiënteerde principe. Welke grote voordelen de toepassing van dit systeem heeft, is genoegzaam bekend. De studenten worden in een vroeger stadium gestimuleerd hun kennisleemten te herkennen, problemen te formuleren en zelf in een bibliotheek met behulp van actuele boek- en tijdschriftliteratuur de problemen op te lossen. Dit onderwijsgroepssysteem kan ook gezien worden als een training voor intercollegiaal overleg, dat met name in de multidisciplinaire klinische oncologie frequent vereist is.

De klinisch oncologen hebben een niet tot één orgaan beperkte deskundigheid op het gebied van de oncologie en kunnen, ondanks hun vrij specialistisch vak, zinvol aan het onderwijs van basisartsen bijdragen. Ook in de pre-klinische fase. Het is derhalve betreurenswaardig dat bij de laatste curriculum herziening het kristallisatiepunt van die aandacht verloren is gegaan. Het goed lopende en goed scorende blok "Tumoren", dat aan het eind van het eerste jaar een overzicht gaf over tumor genese, tumorgedrag en tumortherapie, werd weggesaneerd. Enig kritiekpunt op dit blok kon mogelijkerwijs de plaats in het curriculum zijn. Plaatsing in een later jaar zou hebben kunnen bijdragen in kennisontwikkeling op een hoger integratieniveau dan met de beperkte kennis in het eerste jaar nu eenmaal mogelijk is. Met het verdwijnen van het blok "Tumoren" en het terugbrengen van oncologische problemen fragmentarisch verspreid over de verschillende blokken, met name in het $3 \mathrm{e}$ en het $4 \mathrm{e}$ jaar, is er sprake geweest van een verlies van probleem-georienteerd onderwijs ten. gunste van symptoom-georiënteerd onderwijs. Blokken die thans oncologische problemen aan de orde stellen zijn georiënteerd rond dyspnoe, bloedverlies, moeheid en ouder worden. Dit verlies is gedeeltelijk gecompenseerd met de organisatie van het blok 1.7, "Celgroei", maar de dispersie van m.n. de klinisch oncologische kennisontwikkeling over vele verschillende blokken leidt tot verlies van herkenbaarheid van een groot volksgezondheidsprobleem voor de student. 
De invloed van het $Y$ in is in dat opzicht duidelijk te groot. Onze faculteit is daarmee helaas in de pas met andere Europese faculteiten, waarin docenten erkennen dat over de gehele linie aspecten van het oncologieonderwijs onvoldoende aandacht krijgen. Ook studenten vinden dat er meer aandacht moet zijn voor de ontwikkeling van communicatieve en psychosociale skills, meer tijd nodig is in het curriculum voor oncologie en dat meer praktische blootstelling aan oncologische problemen moiet plaatsvinden.

Onze energie, de Qi zal zich richten op die activeiten die in het Yang projecteren; de organisatie van een klinisch keuze-onderwijsprogramma dat gedurende 6 weken studenten bloot stelt aan oncologische problemen en hun oplossing, zoals die in de verschillende disciplines worden uitgevoerd. Daarmee wordt een meer structurele invulling gegeven dan aan de incidentele contacten die in dit kader nu al bestaan met geïnteresseerde studenten tot groot enthousiasme van zowel studenten als staf. De erkenning van het bestaan van een aandachtsgebied chirurgische oncologie biedt de mogelijkheid ook in de specialistenopleiding structurele aandacht aan de ontwikkeling van kennis en vaardigheid t.b.v. de zorg voor de oncologische patiënt te geven. Daarbij kan gedacht worden aan een keuzeperiode bij een andere dan de eigen in oncologische zorg participerende discipline, zodat de internisten in opleiding bij chirurgen assisteren en assisteren of meewerken in het bestralingsinstituut en omgekeerd chirurgen zich bij de internist of de radiotherapeut oriënteren. Ook hier geldt dat incidentele contacten, zoals die er nu zijn, in positieve zin worden gewaardeerd.

\section{TOT BESLUIT}

Aan het eind gekomen van deze rede rest de voor mij plezierige taak hen te bedanken die eraan hebben bijgedragen, dat ik $u$ hier vandaag kan toespreken. 


\section{MEER VOOR MINDER}

Het College van Bestuur van de Rijksuniversiteit Limburg dank ik voor mijn benoeming tot hoogleraar, en de Raad van Bestuur yan het Academisch Ziekenhuis Maastricht voor mijn gelijktijdige aanstelling tot chirurg. Ik zie emaar uit om - als klinisch hoogleraar - in multidisciplinair verband invulling te geven aan de verdere ontwikkeling van een herkenbaar oncologieprogramma in Maastricht, dat geworteld is in de kliniek, het onderwijs en het onderzoek.

Waarschijnlijk meer nog dan vertegenwoordigers van andere aandachtsgebieden binnen de heelkunde, doet de chirurg-oncoloog een beroep op extra inzet van de medewerkers van vele afdelingen en diensten: radiodiagnostiek, pathologie, anaesthesiologie, polikliniek, dagcentrum, endoscopiekamer, operatiekamer, eerste hulp, verpleging op onze afdelingen, en last but not least het secretariaat, en daarmee ook Wilma. Ik besef, dat de bereidheid die extra inzet steeds opnieuw te leveren niet gelieerd is aan mijn persoon; ik besef (en ben er trots op, dat dat in ons ziekenhuis gebeurt), dat die extra inzet de categorie patiënten geldt, waaraan ik mijn energie wijd.

Hooggeleerde Greep, beste Co,

je hebt een ambiance geschapen in de jonge vakgroep - toen nog capaciteitsgroep - heelkunde waarin benigne vormen van ambitie, competitie, prestatiedrang konden groeien. Die ambiance leidde tot een bundeling van energie die ons jaren vooruit bracht. Ik heb daarvan ruim geprofiteerd.

Hooggeleerde Kootstra, beste Gauke,

$\mathrm{ik}$ bewonder de positieve toon en inzet, waarmee je de harmonie in onze vakgroep weet te bewaren en zorgt voor zicht op onze Tao. Dames en heren, het is een voorrecht te kunnen werken in een chirurgische groep, waarin individuen hun eigen belangen en doelen hebben, maar waarin diezelfde individuen doordrongen zijn van het feit dat bundeling van kracht die individuele ambitie in balans, en ons allen tesamen veel verder brengt. Als wij in dat besef blijven investeren, is aan een belang- 
rijke voorwaarde voor het blijvend zijn van werkplezier voldaan. Hooggeleerden Wesdorp en Soeters, beste Rob en Peter, van jullie heb ik het belangrijkste deel van mijn klinische vorming genoten. Jullie kanaliseerden mijn energie in mijn eerste stappen in het onderzoek en droegen bij aan een verrijkende periode in de Verenigde Staten, toen ik werkte in het lab bij Joe Fischer. Met Peter heb ik de alliantie daarna in het onderzoek voortgezet, hetgeen niet zonder vruchten is gebleven. Het werken in de inmiddels groter geworden groep oncologisch, gastroenterologisch en metabool geïnteresseerden: staf, research staf, arts-assistenten, paramedici en vooral de uitdagende artsassistent onderzoekers, is een dagelijks genoegen; ik hoop het nog lang te beleven en ik zal mij inzetten voor het behoud van een balans, waarin elk zijn gewicht legt.

Mijn ouders dank ik voor mijn vorming; meer dan gemiddeld in Nederland, hebben externe factoren daarin - vaak onverwacht en onvoorzien hun invloed gehad; ik heb dat steeds als een voordeel gezien.

Lieve Ellen en Suzanne, beste Erik; jullie zijn het Qi, het Jing en de Shen, die strijden om de balans, om mij mijn Tao te wijzen.

Ik heb gezegd. 


\section{MEER VOOR MINDER}

\section{GeraAdPleEgde literatuUR}

- Nota Chirurgische Oncologie. Nederlandse Vereniging voor Chirurgische Oncologie. Mei 1994.

- Kwaliteit en taakverdeling in oncologie. Gezondheidsraad. Februari 1993

- Discipline-advies geneeskunde 1994 (ten behoeve van medische faculteiten en buitenuniversitaire instellingen). Koninklijke Nederlandse Akademie van Wetenschappen. Commissie Geneeskunde. 1994

. Hypothesis: Cancer is a metabolic deficiency. Editorial. The Cancer Journal 4; 356, 1991

- Oncologieonderwijs aan Europese medische faculteiten onbevredigend volgens een WHO/UICC-enquête. W Bender, EML Haagedoom, J Oldhoff. Ned Tijdschr Geneesknd $138 ; 1874-1876,1994$

- Glutamine and the immune system. PC Calder. Clinical Nutriton 13;2-8, 1994

- Effects of oral branched-chain amino acids (BCAA) administration in the treatment of cancer anorexia. C Cangiano, A Laviano, I Preziosa, M Mulieri, R Bernardi, A Cascino, M Muscaritoli, L Conversano, F Rossi Fanelli. Clinical Nutrition suppl 1:13;22, 1994

- Klachten over communicatie. RMS Doppegieter. Medisch Contact nr. 40; 1261-1262, 1994

- Anastomotic integrity after operations for large bowel-cancer: a multicentre study. LP Fielding, S Stewart-Brown, L Blesovsky, G Keamey. Br Med J 411-114, 1980

- Energy metabolism in cancer patients. Proefschrift E.W.H.M. Fredrix. Rijksuniversiteit Limburg, Maastricht, 16 maart 1990.

- Medical audit, cancer registration, and survival in ovarian cancer. CR Gillis, DJ Hole, RM Still, J Davis, SB Kaye. The Lancet 337; 611-612, 1991.

- Decrease of mucosal glutamine concentration in the nutritionally depleted patient. RRWJ van der Hulst, NEP Deutz, MF von Meyenfeldt, JHM Elbers, RW Stockbrügger, PB Soeters. Clinical Nutrition 13; 228-233, 1994.

- Surgical Oncology in university departments of surgery in the United States. W. Lawrence, RE Wilson, WW Shingleton, WE Keefe, J Kilpatrick. Arch Surg 121; 1088-1093, 1986 
- Selecting categories of patients for regionalization. Implications of the relationship between volume and outcome. SC Maerki, HS Luft, SS Hunt. Medical Care 24; 148-158, 1986

- Impact of variability among surgeons on postoperative morbidity and mortality and ultimate survival. CS McArdle, D Hole. Br Med J 302; 1501-1505. 1991

- Anorexia and cachexia in cancer; a study with special emphasis on central tryptophan and serotonin metabolism. Proefschrift M.F. von Meyenfeldt, Rijksuniversiteit Limburg, Maastricht, 7 januari 1983.

- Perioperative nutritional suppor in gastric and colorectal cancer patients. Proefschrift W.J.H.J. Meyerink. Rijksuniversiteit Limburg, Maastricht, 16 oktober 1992.

- Local recurrence following "curative" surgery for large bowel cancer: I. The overall picture. RKS Phillips, R Hittinger, L Blesovsky, JS Fry, LP Fielding. Br J Surg 71; 12-16, 1984

- Intestinal glutamine metabolism and nutrition. WW Souba. J Nutr Biochem 4; 2-9, 1993 
Kolen branden dicht op elkaar, als zij zich afscheiden, doven zij oud Oosters gezegde 